Regiony, metropolie, miasta

ISSN 1899-3192

e-ISSN 2392-0041

\author{
Marcelina Zapotoczna \\ Uniwersytet Warmińsko-Mazurski w Olsztynie \\ e-mail: imz@uwm.edu.pl
}

Joanna Cymerman

Politechnika Koszalińska

e-mail: jcymerman@wilsig.tu.koszalin.pl

\title{
DYNAMIKA ZMIAN I PROGNOZY DLA OLSZTYŃSKIEGO RYNKU MIESZKANIOWEGO DYNAMICS OF CHANGES AND FORECASTS FOR THE HOUSING MARKET IN OLSZTYN
}

DOI: $10.15611 / \mathrm{pn} .2017 .467 .24$

JEL Classification: R3

Streszczenie: Publikację poświęcono problematyce olsztyńskiego rynku mieszkaniowego. Celem badań prezentowanych w niniejszej publikacji była analiza cen oraz prognozy dla olsztyńskiego rynku mieszkaniowego. Badania przeprowadzono w oparciu o dane z aktów notarialnych dotyczących sprzedaży lokali mieszkalnych jako przedmiotu prawa własności pozyskane z Rejestru Cen i Wartości Nieruchomości (RCiWN) Wydziału Geodezji i Gospodarki Nieruchomościami Urzędu Miasta Olsztyn, dane statystyki publicznej gromadzone przez GUS oraz raporty i analizy publikowane przez NBP, GUS i AMRON-SARFIN. Przeprowadzone prace badawcze pozwoliły na wskazanie czynników, które miały największy wpływ na koniunkturę na rynku mieszkaniowym w latach 2007-2015 oraz pozwoliły na określenie kierunku, skali i dynamiki zmian zachodzących na olsztyńskim rynku mieszkaniowym, wskazanie trendów oraz sformułowanie prognoz.

Słowa kluczowe: rynek mieszkaniowy, popyt mieszkaniowy, podaż mieszkań, kredyt hipoteczny, programy rządowe.

Summary: The purpose of this research is to analyse the situation on the housing market in Olsztyn. The article focuses on the price scrutiny and the forecasts for the housing market in Olsztyn. The conducted analyses indicate the most valuable factors, which had an impact on the housing market situation in the period 2007-2015. The analysis also revealed the trend. The research data was collected from notarial deeds related to the sale of residential units as an object of property rights, all acts were acquired from the Register of Prices and Values of Real Estates of the Department of Geodesy and Real Estates Administration of the City Councin of Olsztyn (Rejestr Cen i Wartości Nieruchomości - RCiWN Wydziału Geodezji i Gospodarki Nieruchomościami Urzędu Miasta Olsztyn). The characteristics of the housing market in Olsztyn were also assessed using public statistical data collected by the NBP, GUS i AMRON-SARFN. The carried analysis identifies and formulates a forecast of the direction, scale and dynamics of changes on the Olsztyn's housing market.

Keywords: housing market, housing demand, housing supply, mortgage, government programs. 


\section{Wstęp}

Rynek nieruchomości mieszkaniowych jest intrygujący dla badacza, ale zarazem niewdzięczny ze względu na barierę dostępu do danych statystycznych, zwłaszcza dla dużych obszarów, i konieczność budowania długich szeregów czasowych [Foryś 2011]. Zainteresowanie rynkiem mieszkaniowym jako obszarem badań w Polsce wzrosło wraz z odrodzeniem gospodarki rynkowej w latach 90. XX wieku [Kałkowski 2003]. Istotna rola, jaką ten segment odgrywa w gospodarce, wynika z pojmowania nieruchomości nie tylko jako przedmiotu konsumpcji, ale również kapitału, który umożliwia tworzenie korzyści dla właściciela oraz gospodarki lokalnej i krajowej [Trojanek 2008]. Sektor nieruchomości mieszkaniowych odgrywa w sektorze nieruchomości rynkowych kluczową rolę ze względu na swoją wielkość: 7080\% wartości majątku nieruchomości [Łaszek i in. 2009]. Rynek mieszkaniowy należy do kategorii dynamicznych. Tempo i kierunki rozwoju rynku mieszkaniowego zależą od jego potencjału, na który składa się kapitał ekonomiczny, społeczny i polityczny. Rozwój rynku jest ściśle powiązany z rozwojem społecznym, zwłaszcza z cyklem życia rodziny i jej potrzeb mieszkaniowych (zob. szerzej [Andrzejewski 1970]) - każdy etap życia rodziny charakteryzuje się innym poziomem i tempem zmiany dochodów, które rzutują na zdolność ekonomiczną pozyskania i utrzymania mieszkania. Pozyskanie mieszkania przez młode małżeństwo jest momentem zaspokojenia jego potrzeb, jednak z biegiem czasu następuje zmiana potrzeb, zarówno w obszarze parametrów technicznych mieszkania (powierzchni, liczby pokojów, układu funkcjonalnego), jak i potrzeb wyższego rzędu (standardu, lepszej lokalizacji) [Foryś 2011]. Należy w tym miejscu podkreślić lokalny charakter rynku nieruchomości i związane z tym zróżnicowanie przestrzenne procesów rozwojowych oraz siły i kierunku ich oddziaływania na poszczególnych rynkach lokalnych. Powoduje to konieczność prowadzenia analiz dynamicznych w ujęciu przestrzennym.

W pracy przeanalizowano najważniejsze czynniki mające wpływ na koniunkturę na rynku nieruchomości mieszkaniowych w latach 2007-2015, co pozwoliło na określenie kierunku, skali i dynamiki zmian zachodzących na olsztyńskim rynku mieszkaniowym, wskazanie trendów oraz sformułowanie prognoz.

\section{Specyfika rynku mieszkaniowego i uwarunkowania rozwoju}

Rynek mieszkaniowy definiowany jest jako obszar, w którym popyt mieszkaniowy spotyka się z podażą mieszkań, kształtując cenę oraz umożliwiając zawarcie transakcji [Łaszek 2006]. W literaturze przedmiotu zwraca się uwagę na specyfikę rynku mieszkaniowego wyróżniającą go na tle pozostałych sektorów rynku nieruchomości. E. Kucharska-Stasiak wskazuje cztery główne czynniki decydujące o specyfice rynku mieszkaniowego: po pierwsze, powszechność zaspokojenia potrzeb mieszkaniowych - zapewnienie dachu nad głową należy do podstawowych, zagwa- 
rantowanych konstytucyjnie, potrzeb człowieka. Po drugie, dwoistość funkcji, jakie pełni mieszkanie - funkcja społeczna jako podstawowy element zaspokajający podstawowe potrzeby człowieka, oraz funkcja ekonomiczna jako lokata kapitału, obiekt fiskalny, kredytowy. Rynek mieszkaniowy cechuje też duża doza interwencji państwa - głównie przez planowanie przestrzenne, politykę podatkową, ochronę praw lokatorów czy nabywców mieszkań na rynku pierwotnym. Ostatnią ze specyficznych cech rynku mieszkaniowego są zróżnicowane ramy prawne obowiązujące dla różnych pod względem własności zasobów mieszkaniowych [Kucharska-Stasiak 2016].

Jak już wcześniej wspomniano, rynek nieruchomości mieszkaniowych należy do kategorii dynamicznych i podlega nieustannym przemianom. Proces rozwojowy rynku mieszkaniowego jest wypadkową procesów dostosowawczych - opóźnionych w czasie reakcji rynku ${ }^{1}$ na zgłaszane potrzeby mieszkaniowe oraz opóźnionych efektów już wdrożonych innowacji. I. Foryś definiuje rozwój rynku nieruchomości mieszkaniowych jako zmiany ilościowe i jakościowe w tym segmencie identyfikowane za pomocą liczby transakcji zawieranych na rynku, kapitału przepływającego przez ten rynek w przeliczeniu na jednego mieszkańca oraz organizacji procesów [Foryś 2011]. Autorka identyfikuje trzy fazy rozwojowe rynku mieszkaniowego (tab. 1).

Tabela 1. Fazy rozwojowe rynku mieszkaniowego

\begin{tabular}{|c|c|}
\hline $\begin{array}{l}\text { Fazy rozwojowe } \\
\text { rynku } \\
\text { mieszkaniowego }\end{array}$ & Charakterystyka \\
\hline Rynek wschodzący & $\begin{array}{l}\text { - mała liczba ofert sprzedaży i kupna, a tym samym mała liczba transakcji ryn- } \\
\text { kowych, } \\
\text { - ograniczony obrót związany z brakiem kapitału na lokalnym rynku, } \\
\text { - niski poziom obsługi rynku }\end{array}$ \\
\hline $\begin{array}{l}\text { Rynek } \\
\text { rozwijający się }\end{array}$ & $\begin{array}{l}\text { - długotrwała nadpodaż ofert i ograniczona liczba kupujących, niedostatek ka- } \\
\text { pitału kierowanego na rynek lub } \\
\text { - zbyt duża liczba ofert kupna przy ograniczonej podaży (ograniczony zasób } \\
\text { nieruchomości, które mogą być przedmiotem obrotu rynkowego) }\end{array}$ \\
\hline Rynek rozwinięty & $\begin{array}{l}\text { - wzrost liczby ofert sprzedaży i kupna oraz zawieranych transakcji, } \\
\text { rozwinięty sektor specjalistycznych usług świadczonych uczestnikom obrotu } \\
\text { rynkowego, } \\
\text { - wysoki poziom organizacji rynku przejawiający się w instrumentach zapew- } \\
\text { niających sprawność i bezpieczeństwo obrotu }\end{array}$ \\
\hline
\end{tabular}

Źródło: opracowanie własne na podstawie [Foryś 2011].

1 Opóźnione w czasie reakcje rynku stanowią efekt małej elastyczności cenowej podaży mieszkań, tj. powolnej, mniej niż proporcjonalnej reakcji podaży na zmiany cen. Wynika to ze specyfiki procesu inwestycyjnego na rynku nieruchomości, który trwa minimum kilkanaście miesięcy. 
Rozwój rynku mieszkaniowego jest uwarunkowany wieloma czynnikami o zróżnicowanym charakterze. W podejściu podażowo-popytowym przyjmuje się założenie, że czynniki determinujące popyt i podaż na rynku mieszkaniowym są jednocześnie czynnikami determinującymi jego rozwój. Determinantami po stronie popytu są potrzeby mieszkaniowe (czynnik społeczny) oraz kapitał niezbędny do sfinansowania tych potrzeb (czynnik gospodarczy). Po stronie determinant podażowych wymienia się stan ilościowy i jakościowy zasobu mieszkaniowego oraz dynamikę inwestycji [Foryś 2011]. W ujęciu dynamicznym zakłada się, że impulsy pobudzające lokalne rynki mieszkaniowe płyną z otoczenia gospodarczego, społecznego, politycznego i prawno-organizacyjnego. Bodźcem rozwojowym rynku jest przepływ kapitału ludzkiego w przestrzeni, zmiana jego stanu i struktury w czasie i związane z tym zmiany społeczne (potrzeby, preferencje). Drugim niezbędnym czynnikiem jest ruch kapitału oznaczający przesuwanie kapitałów, w tym oszczędności, do sektora mieszkaniowego. W efekcie następuje ruch w sektorze mieszkaniowym, nowe inwestycje i transakcje.

\section{Metodyka}

Celem badań prezentowanych w niniejszej publikacji była analiza najważniejszych czynników mających wpływ na sytuację na olsztyńskim rynku mieszkaniowym w latach 2007-2015, wskazanie trendów oraz sformułowanie prognoz. Zaprezentowane $\mathrm{w}$ pracy badania przeprowadzono w oparciu o dane $\mathrm{z}$ aktów notarialnych dotyczących sprzedaży lokali mieszkalnych jako przedmiotu prawa własności pozyskane z Rejestru Cen i Wartości Nieruchomości (RCiWN) oraz raporty i analizy publikowane przez NBP, GUS i AMRON-SARFIN. Porównania cen ofertowych i transakcyjnych na rynku pierwotnym i wtórnym dokonano na podstawie danych publikowanych przez NBP - Bazy cen nieruchomości mieszkaniowych. Dane RCiWN poddano analizie. W pierwszym etapie wyselekcjonowano transakcje, które zawierały informacje dotyczące cen transakcyjnych $1 \mathrm{~m} \mathrm{kw}$. lokalu, formy obrotu, obrębu, powierzchni użytkowej, położenia na kondygnacji oraz roku budowy. Następnie brakujące dane uzupełniono na podstawie ksiąg wieczystych w zakresie informacji zawartych w tych księgach. Ostatecznie do analiz przyjęto 10632 transakcji. W analizie trendów rocznych zmian cen transakcyjnych posłużono się medianami cen transakcyjnych nieruchomości mieszkaniowych, co pozwoliło na uniknięcie wpływu pojedynczych wartości cen transakcyjnych znacznie odchylających się od wartości cen typowych dla całego zbioru transakcji w danym roku. Medianami posłużono się również przy analizie obrotu mieszkaniami według powierzchni użytkowej. Długi okres przyjęty do analizy pozwolił zauważyć rysujące się trendy i kierunki zmian na olsztyńskim rynku mieszkaniowym w zakresie obrotu mieszkaniami według cen transakcyjnych, przeciętnej powierzchni oraz wieku budynku. 


\section{Dynamika zmian na olsztyńskim rynku mieszkaniowym w latach 2007-2015}

Punktem wyjścia do analizy była diagnoza stanu sytuacji mieszkaniowej mieszkańców Olsztyna, opisana wielkością zasobu mieszkaniowego w kontekście liczby mieszkańców oraz zmian demograficznych prognozowanych przez GUS, podstawowych wskaźników oceny warunków mieszkaniowych, struktury i dynamiki nowo budowanych i oddawanych do użytkowania mieszkań ${ }^{2}$ oraz dostępności dochodowej mieszkań.

Miasto Olsztyn jest stolicą województwa warmińsko-mazurskiego, które zamieszkuje ponad 173 tys. osób. Pomimo trudnej sytuacji demograficznej odnotowywanej w większości polskich miast, w Olsztynie, w badanym okresie, tj. w latach 2007-2015, nie odnotowano istotnej zmiany liczby mieszkańców. Jedynie w roku 2013 odnotowano niewielki ujemny przyrost naturalny (-0,2/1000 ludności). Natomiast $\mathrm{w}$ wyniku migracji wewnętrznych i zagranicznych liczba mieszkańców zmniejszyła się zaledwie o 1\%. Jednak, co należy podkreślić, w badanym okresie obserwowano zmianę struktury populacji Olsztyna. W całym analizowanym okresie największą grupę mieszkańców stanowiły osoby w wieku od 25 do 34 lat, niemniej jednak była to grupa coraz mniej liczna. Największy wzrost liczby ludności odnotowano w przedziale wiekowym 35-44 lata oraz osób w wieku emerytalnym. W tym samym czasie o jedną trzecią zmniejszyła się liczba mieszkańców w wieku 13-19 lat i o połowę w wieku 20-24 lata. Zmieniająca się struktura wiekowa ludności oraz dynamika tych zmian wskazują na starzenie się społeczeństwa Olsztyna, co ma istotny wpływ na zmiany w natężeniu zaspokajania potrzeb mieszkaniowych. Rosnąca liczba ludności w wieku emerytalnym jest konsekwencją nie tylko wyżu demograficznego z lat 50., ale również wydłużania się przeciętnej długości trwania życia. Należy zatem oczekiwać zmian na rynku mieszkaniowym, wynikających głównie z uzyskiwania mniejszych dochodów przez osoby w wieku emerytalnymi związanych z tym mniejszych możliwości finansowych utrzymania mieszkań. Stąd wynika rysująca się zmiana preferencji wśród osób w wieku emerytalnym, szczególnie w zakresie powierzchni zajmowanego mieszkania. Z kolei, mając na uwadze rosnącą liczbę mieszkańców z grupy trzydziesto- i czterdziestolatków, tj. osób charakteryzujących się największą aktywnością zawodową oraz najczęściej posiadających już mieszkania, należy przypuszczać, że osoby te będą dążyć do poprawy warunków mieszkaniowych, oczywiście zgodnie z indywidualnymi preferencjami i możliwościami finansowymi. W kontekście obserwowanych zmian demograficznych dokonano analizy sytuacji mieszkaniowej mieszkańców Olsztyna. Obliczone wartości podstawowych wskaźników oceny warunków mieszkaniowych wskazują na poprawę sytuacji mieszkaniowej w analizowanym okresie. W roku 2015 na 1000

2 Analizy struktury dokonano, wykorzystując dane GUS-u, przyjmując kryterium podziału nowych inwestycji według GUS-u. 
mieszkańców przypadały 434 mieszkania, co oznacza wzrost wartości wskaźnika o $35 \mathrm{w}$ porównaniu z rokiem 2007. Porównanie z medianą dla miast wojewódzkich, odchylenie procentowe w stosunku do przeciętnej wartości, dało wynik o $0,6 \%$ większy od wartości, której nie osiągnęła połowa miast wojewódzkich. Zmniejszyła się również liczba osób przypadająca na 1 izbę - z 0,74 do 0,67 , co oznacza wynik identyczny, jaki osiągnęła połowa miast wojewódzkich. Wzrosła przeciętna powierzchnia użytkowa przypadająca na 1 osobę - z 22,4 do 25,2 m kw. p.u. Jednak jest to wynik mniejszy o 5,6\% od wartości, której nie osiągnęła połowa stolic województw, tzn. mediany. Poprawa warunków mieszkaniowych nastąpiła głównie dzięki realizowanym nowym inwestycjom. Według danych GUS-u w latach 2007-2015 oddano do użytkowania 9837 mieszkań3 ${ }^{3}$. Najwięcej mieszkań w każdym badanym roku budowano na sprzedaż lub wynajem (od 2010 do 2014 r. blisko 80\% ogólnej liczby oddanych do użytkowania mieszkań). Liczba realizowanych inwestycji w systemie indywidualnym ulegała znacznym wahaniom. W latach 2007-2009 inwestorzy indywidualni stanowili znaczącą grupę pod względem liczby realizowanych inwestycji (ponad 20\% mieszkań oddanych do użytkowania). W kolejnych latach ich udział zmniejszył się do nieco ponad 10\%. Zmarginalizowana została rola spółdzielni mieszkaniowych, a TBS-y jedynie w co drugim roku analizy oddawały mieszkania do użytkowania.

Jednym z głównych czynników decydujących o warunkach mieszkaniowych jest średnie wynagrodzenie uzyskiwane przez pracownika etatowego lub średni dochód przypadający na członka rodziny. Obliczone wskaźniki dostępności dochodowej mieszkań ${ }^{4}$ wskazują na poprawę sytuacji w latach 2008-2014. W 2008 roku wartość wskaźnika kształtowała się na poziomie 6,78 , co oznacza występującą wysoką niedostępność mieszkań, w roku 2014 zaś obliczona wartość wskaźnika na poziomie 4,32 wskazywała na występowanie umiarkowanej niedostępności. Głównym czynnikiem ograniczającym dostępność dochodową mieszkań były uzyskiwane przez gospodarstwa domowe niskie dochody oraz niskie tempo ich wzrostu, przy średnich cenach mieszkań wykazujących stały wzrost do 2011 roku. W następnych latach odnotowano spadek średnich cen, które w latach 2014 i 2015 zbliżyły się do poziomu z roku 2009. Analizując przeciętne miesięczne wynagrodzenie brutto mieszkańców Olsztyna, stwierdzono, że w roku 2014 wystarczało na zakup $0,98 \mathrm{~m}$ kw. p.u. mieszkania na rynku wtórnym i $0,87 \mathrm{~m}$ kw. p.u. mieszkania na rynku pierwotnym, co oznacza, że w porównaniu z rokiem 2008 można było ku-

3 GUS uznawał za odrębne mieszkania domy, w których kuchnia, łazienka lub ustęp nie były użytkowane wspólnie przez zamieszkujące tam gospodarstwa. Słowo „mieszkanie” w tym statystycznym kontekście odnosi się zarówno do lokali mieszkalnych, jak i domów jednorodzinnych.

4 Wskaźniki dostępności dochodowej obliczono jako iloraz ceny (mediana ceny za przeciętną wielkość mieszkania będącą przedmiotem transakcji na wolnym rynku w Olsztynie w danym roku) do dochodu rocznego gospodarstwa domowego (mediana dochodu brutto uzyskiwana przez gospodarstwa domowe mieszkające na terenie miasta Olsztyn w danym roku). Obliczeń dokonano na podstawie danych o transakcjach pozyskanych z Urzędu Miasta w Olsztynie - RCiWN oraz danych US w Olsztynie. 
pić o $0,16 \mathrm{~m}$ kw. p.u. mieszkania więcej na rynku pierwotnym i o $0,31 \mathrm{~m}$ kw. p.u. mieszkania więcej na rynku wtórnym. Wprawdzie wskaźniki pokazują niewielkie, ale stałe tempo poprawy warunków mieszkaniowych mieszkańców Olsztyna, jednak nadal są to warunki niekorzystne, paradoksalnie zaś zachodzące zmiany demograficzne, czyli spadek liczby ludności ${ }^{5}$, mogą wpłynąć na ich poprawę.

\section{Czynniki kształtujące i prognozy dla olsztyńskiego rynku mieszkaniowego}

W dalszej części pracy zaprezentowano wyniki analiz przeprowadzonych dla olsztyńskiego rynku mieszkaniowego na podstawie danych o transakcjach nieruchomościami lokalowymi (lokalami mieszkalnymi) z lat 2007-2015. Przeprowadzone analizy pozwoliły na określenie kierunku, skali i dynamiki zachodzących zmian, wskazanie trendów oraz sformułowanie prognoz.

Punktem wyjścia do analizy był rok 2007, w którym to, mimo lat transformacji, nadal sektor mieszkaniowy określano jako niestabilny i słabo uregulowany, a w wyniku przegrzanej koniunktury inwestycji w nieruchomości mieszkaniowe doszło do niekontrolowanego wzrostu cen. Na rynku wtórnym odnotowano znacznie wyższe średnie ceny transakcyjne w porównaniu z rynkiem pierwotnym (rys. 1).

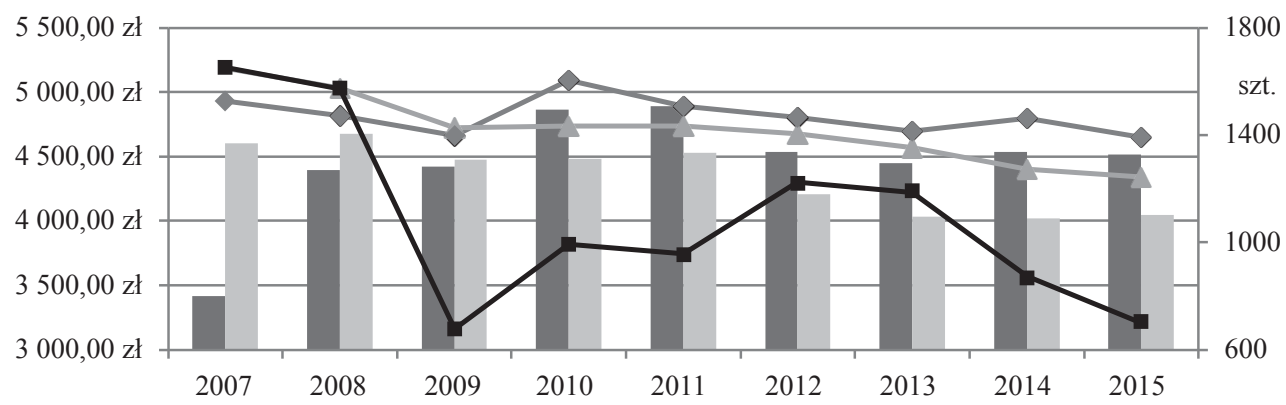

rynek pierwotny - ceny transakcyjne
$ـ$ rynek pierwotny - ceny ofertowe
$ـ$ - liczba oddawanych do użytkowania mieszkań

rynek wtórny - ceny transakcyjne

- rynek wtórny - ceny ofertowe

Rys. 1. Porównanie średnich cen transakcyjnych i ofertowych na pierwotnym i wtórnym olsztyńskim rynku mieszkaniowym w latach 2007-2015

Źródło: opracowanie własne na podstawie danych NBP.

Występujący w Polsce deficyt mieszkaniowy przy niezaspokojonych potrzebach mieszkaniowych wymagał zrównoważonego podejścia państwa do wspierania

5 Według danych GUS-u liczba ludności w Olsztynie zmniejszy się w 2030 r., w porównaniu z rokiem 2014, o 4,3\%, do roku 2050 zaś, w porównaniu z rokiem 2014, o 14,7\%. 
mieszkalnictwa, tj. działań po stronie zarówno popytowej, jak i podażowej. Ponadto każda alternatywna forma wspierania gospodarstw domowych w zaspokajaniu potrzeb mieszkaniowych powinna była być dostosowana do ich możliwości ekonomicznych. Taką formą wsparcia finansowego był przez wiele lat system dotacji, szczególnie popytowych, oraz instrumenty podatkowe. Rozwój sektora finansowego przesunął ciężar finansowego wsparcia na rozwój rynku hipotecznych kredytów mieszkaniowych. Dostęp do kredytów miał ogromny wpływ na wzrost rozmiarów budownictwa mieszkaniowego, który był odpowiedzią na potrzeby mieszkaniowe, a w efekcie na popyt mieszkaniowy. Gospodarstwa domowe w Polsce nie miały zbyt wiele czasu na akumulowanie oszczędności, tak więc nie miały też czasu na akumulowanie kapitału, który mógłby posłużyć do zakupu mieszkania. Dlatego duży odsetek zakupów mieszkaniowych finansowany był mieszkaniowym kredytem hipotecznym. Przyrost zadłużania się gospodarstw domowych w polskich bankach z tytułu kredytów hipotecznych dobrze ilustruje nadwyżkę popytu nad podażą na rynku mieszkaniowym. Jednak odnotowane po 2008 roku spowolnienie polskiej gospodarki nie pozostało bez wpływu na kondycję rynku. Stało się przyczyną niewykorzystania potencjału finansowania kredytem hipotecznym zakupów mieszkaniowych. Wśród przyczyn wymieniano wówczas rosnące oprocentowanie kredytów, wahania kursów walut, a także zachowawcze podejście do kredytu czy nawet negatywny stosunek do zadłużania się w sytuacji rodzącego się strachu przed utratą zatrudnienia, czego przyczyną było rosnące bezrobocie (według danych GUS-u w Olsztynie nastąpił wzrost o 3 pkt proc., porównując rok 2009 do 2008). Rosnąca przewaga popytu nad podażą na olsztyńskim rynku mieszkaniowym, przejawiająca się wzrostem cen mieszkań w latach 2007-2010, została zahamowana wzrostem oprocentowania kredytów hipotecznych, co odwróciło tendencje. Spadek akcji kredytowej nastąpił już w drugim półroczu 2008 r. i obserwowany jest do dzisiaj. Od 2010 roku następowało stopniowe zwiększanie się liczby nowo udzielanych kredytów, jednak nadal jest ona mniejsza niż w roku 2008. Słabnąca dynamika udzielanych kredytów mieszkaniowych i jednoczesny wzrost podaży nowych mieszkań od 2010 r. działały równoważąco na rynek. Średnie cenylm kw. mieszkania na rynku pierwotnym stały się wyższe niż na rynku wtórnym (rys. 1). Wzrost o $29 \%$ średnich cen na rynku pierwotnym oraz utrzymujące się wysokie ceny na rynku wtórnym w latach 2007-2009 związane były z niską podażą nowo budowanych mieszkań. Rok 2009 był najtrudniejszym rokiem dla deweloperów na olsztyńskim rynku mieszkaniowym. Oddano wówczas do użytkowania najmniejszą liczbę mieszkań (rys. 1). W roku 2010, po kryzysowym roku 2009, odnotowano niewielki wzrost wprowadzanych na rynek nowych inwestycji (o 14\%), co przełożyło się na liczbę mieszkań oddawanych do użytkowania w kolejnych latach. Pomimo wzrostu podaży nadal w latach 2010-2011 odnotowywano wzrost średniej ceny $1 \mathrm{~m}$ kw. p.u. mieszkania, na co wpływ miały obniżki stóp procentowych kredytów mieszkaniowych oraz ciągle niezaspokojone potrzeby mieszkaniowe. Ponadto wzrost poda- 
ży mieszkań na rynku pierwotnym spełniających kryteria kredytu preferencyjnego ${ }^{6}$ i związany z tym wzrost zainteresowania zakupami mieszkaniowymi spowodowały spadek cen na rynku wtórnym w latach 2011-2013 przeciętnie rocznie o 7\% (rys. 1). Po fali wzrostu trwającej do $2011 \mathrm{r}$. średnie ceny na rynku pierwotnym wróciły do poziomu z roku 2009 i nadal pozostają na dość stabilnym poziomie, tj. obserwuje się niewielki poziom wahań. Ponadto należy podkreślić, że rok 2013 był ostatnim rokiem zakupu mieszkań przy pełnym finansowaniu kredytem hipotecznym, ponieważ przepisy znowelizowanej rekomendacji $\mathrm{S}$ wprowadziły wymóg posiadania wkładu własnego przy kredycie hipotecznym, co miało istotny wpływ na decyzje zakupowe na rynku mieszkaniowym. Należy przypuszczać, że stopniowe zwiększanie minimalnego wkładu własnego (minimalny wkład własny przy kredycie hipotecznym w 2014 r. wynosił 5\%; od 2017 r. - 20\%) z czasem może ograniczyć dostęp do kredytów, głównie dla ludzi młodych, myślących o zakupie swojego pierwszego mieszkania. Wspierać młodych ludzi w nabywaniu pierwszego mieszkania miał wprowadzony w $2014 \mathrm{r}$. kolejny program rządowy - Mieszkanie dla Młodych? ${ }^{7}$ Program miał się przyczynić do regulacji cen, jak również wzrostu popytu i podaży. Jednak ze względu na małą podaż mieszkań spełniających kryteria MdM, program nie miał większego wpływu na pierwotny rynek mieszkaniowy. Od 2014 roku gwałtownie zmalała liczba oddanych do użytku mieszkań nowych inwestycji (rys. 1). Jednakże biorąc pod uwagę liczbę wydanych pozwoleń na budowę oraz inwestycji rozpoczętych w 2015 r., należy spodziewać się wysokiej podaży na rynku pierwotnym w następnych latach, a zatem również wzrostu popytu na kredyty hipoteczne. Należy również przypuszczać, że banki będą starały się obniżać wymagany poziom środków własnych do $10 \%$, zgodnie z możliwościami, jakie daje rekomendacja S, lub łagodzić skutki podwyżki wkładu własnego, wprowadzając inne

6 Zwany kredytem z dopłatą, realizowany w ramach rządowego programu Rodzina na Swoim, dający możliwość uzyskania przez pierwsze osiem lat spłaty kredytu zaciąganego na zakup mieszkania czy domu dopłaty do miesięcznej raty kwoty stanowiącej równowartość połowy raty odsetkowej. Program preferencyjnych kredytów został wprowadzony na mocy Ustawy z dnia 8 września 2006 r. o finansowym wsparciu rodzin w nabywaniu własnego mieszkania. Wnioski kredytowe w ramach programu można było składać do 2012 roku. Ostatnie umowy zawarto w 2013 roku. Najwięcej kredytów udzielono w latach 2010-2012. Według danych Banku Gospodarstwa Krajowego udzielono łącznie 192360 kredytów na kwotę ponad 35 mld zł.

7 Podobnie jak w przypadku programu RnS, program Mieszkanie dla Młodych jest rządową subsydią. Zasady programu reguluje Ustawa z dnia 27 września 2013 r. o pomocy państwa w nabyciu pierwszego mieszkania przez młodych ludzi. W ramach programu osoby, które nie ukończyły 35 lat, mogą otrzymać dofinansowanie na zakup pierwszego własnego mieszkania. Wartość dopłaty może wynieść nawet 30\% wartości mieszkania i ma stanowić część wkładu własnego, jaki jest wymagany przy zaciąganiu kredytu hipotecznego. Nowelizacja ustawy z dnia 25 czerwca 2015 r. zniosła kryterium wieku i warunku pierwszego mieszkania dla gospodarstw domowych z co najmniej trójką dzieci, zwiększono metraż, co do którego przysługiwała dopłata, rozszerzono zakres wsparcia o rynek wtórny, wprowadzono również możliwość uzyskania dofinansowania na wkład budowlany do spółdzielni mieszkaniowej. Funkcjonowanie programu przewidziano na lata 2014-2018. Celem programu była także stymulacja rynku mieszkaniowego. 
narzędzia, np. oferując pożyczkę na wkład własny lub łagodząc system obliczania zdolności kredytowej ${ }^{8}$.

Dokonując analizy pod kątem rozpiętości cen, stwierdzono, że największą rozpiętość cen ofertowych i transakcyjnych na rynku pierwotnym odnotowano w 2007 r. (44\%), co sugeruje elastyczność nabywców przy małej podaży i rosnącym popycie. Od 2009 roku różnica nie przekroczyła 6\%. Natomiast większe zróżnicowanie oferty na rynku wtórnym spowodowało większą rozpiętość cen, szczególnie w okresie największej aktywności działania programu RnS. Największą różnicę odnotowano w latach 2012-2014 (odpowiednio 11,26\%, 13,27\%, 9,44\%) (rys. 1).

Analizując mediany cen transakcyjnych mieszkań, stwierdzono systematyczny ich spadek już od połowy $2008 \mathrm{r}$. o 5,33\%, w całym analizowanym okresie zaś o 8,45\%, a kolejne lata mogą przynieść jeszcze kilkuprocentowe spadki cen, na co będą miały wpływ prognozowane negatywne wskaźniki demograficzne. Roczne trendy cen potwierdzają zmiany zachodzące na rynku mieszkaniowym w Olsztynie. Największe wahania cen odnotowano w 2007 r. (wzrost cen o 38,46\%), na co miał wpływ dynamiczny wzrost popytu przy niewielkiej podaży mieszkań. W kolejnym, 2008 r. spowolnienie polskiej gospodarki przyczyniło się do spadku cen o 7,36\%. Na występujące w kolejnych latach analizy roczne zmiany cen wpływ miały rządowe subsydia oraz polityka kredytowa banków. Należy przy tym podkreślić, iż narzucone limity cenowe programu MdM mogły wpłynąć na wzrost cen w sektorze najtańszych mieszkań w 2014 r., w 2015 r. zaś na obniżenie cen, z uwagi na objęcie programem rynku wtórnego oraz zapowiadany wzrost wymaganego wkładu własnego przy hipotecznych kredytach mieszkaniowych, a także zmniejszającą się pulę środków w programie MdM (rys. 2).

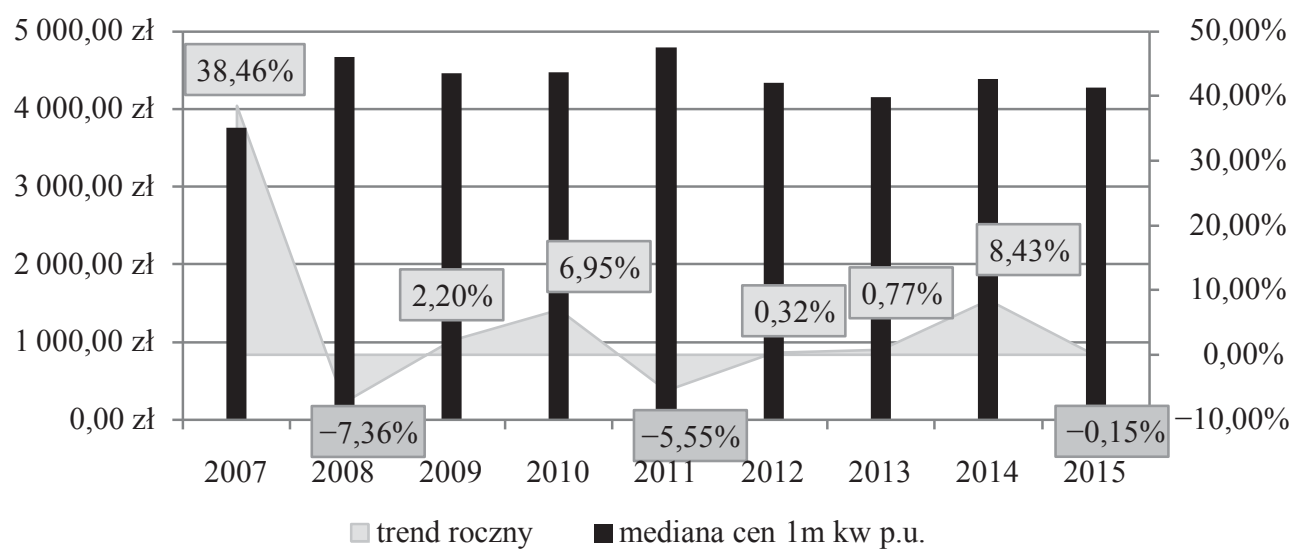

Rys. 2. Trendy roczne zmian cen oraz mediany cen transakcyjnych mieszkań na olsztyńskim rynku mieszkaniowym w latach 2007-2015

Źródło: obliczenia własne na podstawie danych o transakcjach z RCiWN.

${ }^{8}$ Podobne stanowisko prezentuje część specjalistów Polskiej Federacji Rynku Nieruchomości. 
Analizując mediany cen transakcyjnych na olsztyńskim rynku mieszkaniowym, można zauważyć, że do roku 2011 dominował obrót mieszkaniami najdroższymi, tj. po cenie powyżej $4500 \mathrm{zł}$ za $1 \mathrm{~m} \mathrm{kw}$. W roku 2011 odnotowano największą w badanym okresie liczbę transakcji w tym przedziale cenowym, stanowiącą aż 61,30\% transakcji ogółem. Od 2012 roku nastąpił wzrost obrotu mieszkaniami z przedziału cenowego od 3000 zł do 4000 zł oraz powyżej 4000 zł do 4500 zł. Natomiast najmniejszy odsetek transakcji dotyczył mieszkań najtańszych, tj. do 3000 zł (oprócz roku 2007) (rys. 3).

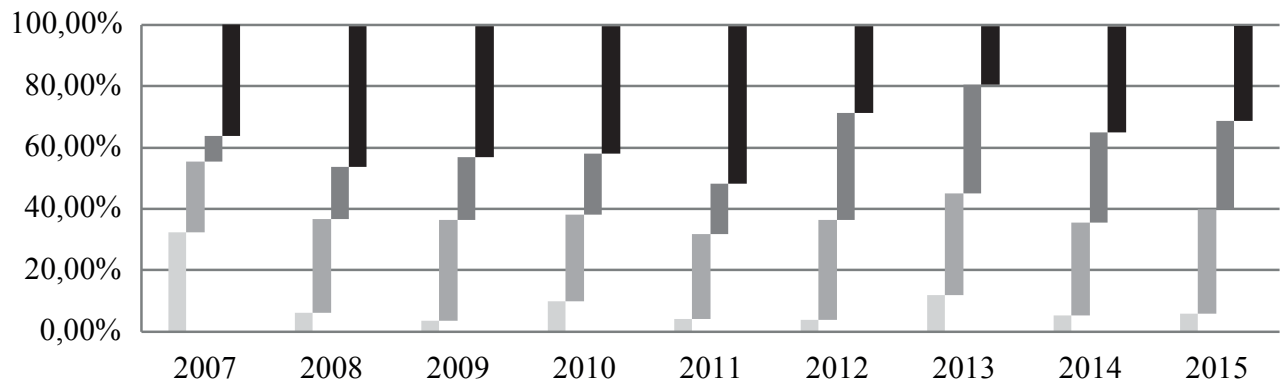

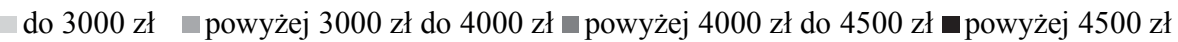

Rys. 3. Rozkład transakcji według cen transakcyjnych na olsztyńskim rynku mieszkaniowym w latach 2007-2015

Źródło: obliczenia własne na podstawie danych z RCiWN.

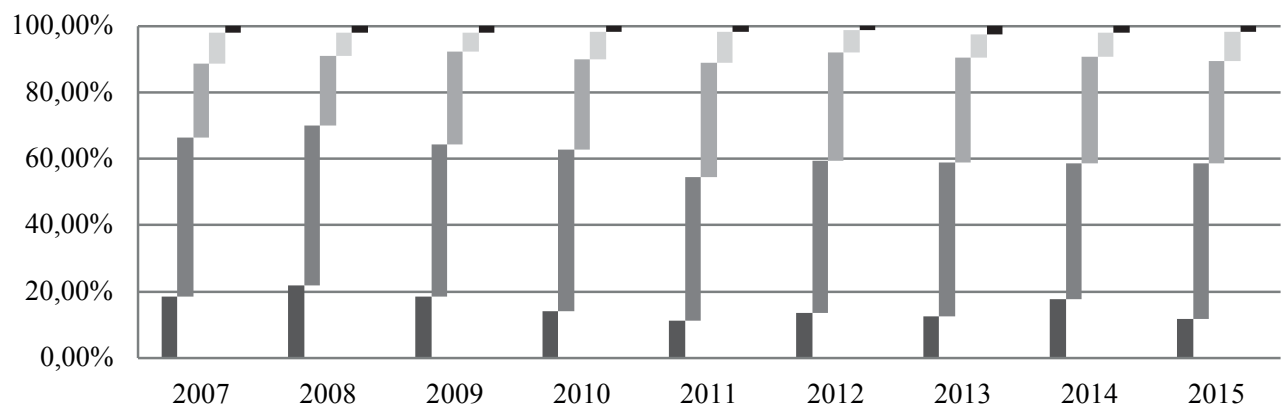

a do $35 \mathrm{mkw} \square$ od 35 do $50 \mathrm{mkw} \square$ od $50 \mathrm{mkw}$ do $70 \mathrm{mkw} \quad$ od 70 do $100 \mathrm{mkw} \square$ pow $100 \mathrm{mkw}$

Rys. 4. Obrót mieszkaniami na olsztyńskim rynku mieszkaniowym w latach 2007-2015 według powierzchni użytkowej

Źródło: obliczenia własne na podstawie danych z RCiWN.

W każdym analizowanym roku dominował obrót mieszkaniami małymi, o powierzchni od 35 do $50 \mathrm{~m}$ kw. p.u., które najczęściej kupowały osoby młode, wchodzące na rynek pracy, usamodzielniające się lub też osoby z myślą o czerpaniu 
dochodów z wynajmu. Inwestycja w mieszkanie na wynajem stała się dobrą alternatywą dla nisko oprocentowanych lokat bankowych. Na uwagę zasługuje natomiast słabnąca popularność mieszkań najmniejszych, tj. o powierzchni do $35 \mathrm{~m}$ kw. p.u. (rys. 4).

Należy wnioskować, że trend taki będzie się utrzymywał, ponieważ nabywcami najczęściej były osoby w wieku od 20 do 34 lat, których liczba znacznie się zmniejszyła w ciągu badanego okresu, a prognozy demograficzne wskazują na utrzymanie się takiego trendu. Struktura mediany cen transakcyjnych pokazuje, że mimo zaostrzenia polityki kredytowej, na olsztyńskim rynku mieszkaniowym utrzymywała się dobra koniunktura, na co wskazuje stale rosnąca liczba transakcji.

W całym analizowanym okresie dużą popularnością cieszyły się również mieszkania trzy-, czteropokojowe o powierzchni użytkowej od 50 do $75 \mathrm{~m}$ kw. (rys. 4). Takie mieszkania kupowane były głównie przez trzydziesto- i czterdziestolatków, najczęściej posiadających już własne mieszkania, którzy starali się poprawić swoje warunki mieszkaniowe. Trend ten będzie się utrzymywał jeszcze przez kolejne lata $\mathrm{z}$ uwagi na największy wzrost liczby ludności w tym przedziale wiekowym.

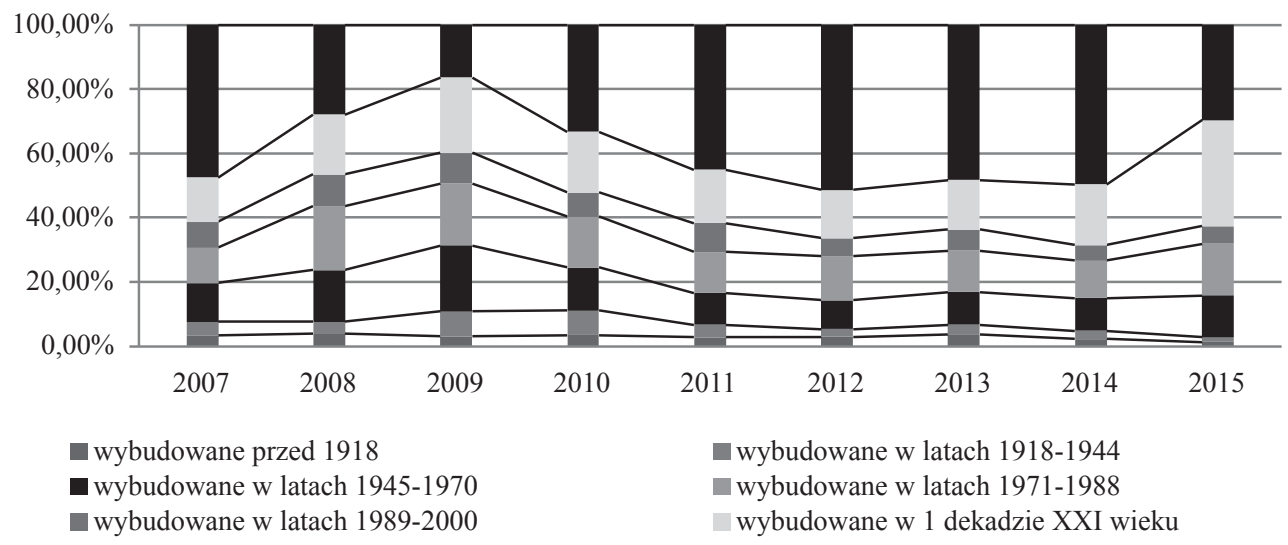

Rys. 5. Obrót mieszkaniami na olsztyńskim rynku mieszkaniowym w latach 2007-2015 według wieku budynku

Źródło: obliczenia własne na podstawie danych z RCiWN.

Na rynku olsztyńskim dominował obrót mieszkaniami nowo wybudowanymi. Drastyczny spadek podaży w roku 2009 spowodował, że liczba transakcji nowo wybudowanymi lokalami w tym roku była najmniejsza wśród badanych lat i stanowiła zaledwie 16,32\% transakcji ogółem. Na rynku wtórnym najchętniej kupowano mieszkania wybudowane w pierwszej dekadzie XXI wieku. Największy obrót tymi lokalami odnotowano w 2015r. (33,02\% transakcji ogółem) i był to jednocześnie największy wzrost w porównaniu z latami poprzednimi, tj. o ok. 83\% (rys. 5). Tak duży wzrost transakcji spowodowany był otwarciem programu MdM na rynek 
wtórny. Dużym zainteresowaniem cieszyły się również mieszkania wybudowane w okresie powojennym oraz w latach 70. i 80. XX wieku. Największy obrót tymi lokalami odnotowano w roku 2009. Przedmiotem co trzeciej transakcji było mieszkanie wybudowane we wspomnianym okresie. Z kolei najmniejszy odsetek stanowiły transakcje lokalami wybudowanymi przed 1918 rokiem (rys. 5).

Przeprowadzona analiza pozwoliła na ocenę skali podaży i chłonności olsztyńskiego rynku mieszkaniowego w latach 2007-2015 oraz wskazanie trendów na nim występujących i sformułowanie prognoz.

\section{Zakończenie}

W pracy przedstawiono wyniki analiz procesów zachodzących na rynku nieruchomości mieszkaniowych. Wskazano najważniejsze czynniki, które miały wpływ na sytuację na olsztyńskim rynku mieszkaniowym w analizowanym okresie, ustalono kierunek, skalę i dynamikę zmian, wskazano trendy oraz sformułowano prognozy. Olsztyński rynek mieszkaniowy pod wieloma względami wykazywał zróżnicowane tendencje, na co wpływało wiele czynników. Do głównych czynników generujących popyt zaliczono: sytuację demograficzną, sytuację na rynku pracy, rosnące zaufanie do inwestycji deweloperskich, zwłaszcza po wejściu w życie ustawy tzw. deweloperskiej [Ustawa z dnia 16 września 2011 r.], niskie oprocentowanie depozytów, co skłaniało osoby posiadające zasoby gotówkowe do inwestycyjnych zakupów nieruchomości mieszkaniowych, oprocentowanie kredytów, możliwość uzyskania dopłat z programów rządowych, jak również perspektywę wzrostu wymaganego wkładu własnego dla uzyskania kredytów hipotecznych w ostatnich dwóch latach analizy. W analizowanym okresie obserwowano zróżnicowaną aktywność rynku. Na wahania cen ofertowych i transakcyjnych na rynku pierwotnym i wtórnym miały wpływ zmieniające się relacje między popytem i podażą. Na rynku pierwotnym deweloperzy starali się dobrze dopasować nowe projekty do popytu. Na zróżnicowanie cen miały wpływ subsydia rządowe wspierające nabywców mieszkań spełniających określone w programach kryteria oraz warunki uzyskania kredytu na zakup mieszkania. Analiza skali zapotrzebowania wskazuje na uzasadniony rozwój rynku, jednak liczba budowanych mieszkań wciąż była niewystarczająca.

\section{Literatura}

Andrzejewski A., 1970, Potrzeby mieszkaniowe. Problemy i perspektywy, Państwowe Wydawnictwo Wiedza Powszechna, Warszawa.

Domański R., 1993, Kapital ludzki i wzrost gospodarczy, PWN, Warszawa.

Foryś I., 2011, Społeczno-gospodarcze determinanty rozwoju rynku mieszkaniowego w Polsce. Ujęcie ilościowe, Wydawnictwo Naukowe Uniwersytetu Szczecińskiego, Szczecin. 
Kałkowski L., 2003, Rynek nieruchomości w Polsce, Twigger, Warszawa.

Kucharska-Stasiak E., 2016, Ekonomiczny wymiar nieruchomości, Wydawnictwo Naukowe PWN, Warszawa.

Łaszek J., 2006, Rynek nieruchomości mieszkaniowych i jego specyfika jako czynniki determinujące ryzyko kredytowania hipotecznego, Materiały i Studia NBP, z. 203.

Łaszek J., Augustyniak H., Widłak M., 2009, Euro a ryzyko bąbli na rynku nieruchomości mieszkaniowych, Materiały i Studia NBP, z. 238.

Trojanek R., 2008, Wahania cen na rynku mieszkaniowym, Wydawnictwo Akademii Ekonomicznej w Poznaniu, Poznań.

Ustawa z dnia 8 września 2006 r. o finansowym wsparciu rodzin w nabywaniu własnego mieszkania, DzU 2006, nr 183, poz. 1354 z późn. zm.

Ustawa z dnia 16 września 2011 r. o ochronie praw nabywcy lokalu mieszkalnego lub domu jednorodzinnego, DzU $2011 \mathrm{nr}$ 232, poz. 1377.

Ustawa z dnia 27 września 2013 r. o pomocy państwa w nabyciu pierwszego mieszkania przez młodych ludzi, DzU 2013, poz. 130, z późn. zm.

www.stat.gov.pl.

Ogólnopolski raport o kredytach mieszkaniowych i cenach transakcyjnych nieruchomości. Raporty AMRON I SAFRIN za lata 2010-2015; www.amron.pl.

Bazy cen nieruchomości mieszkaniowych, https://www.nbp.pl/publikacje/rynek_nieruchomosci/ceny mieszkan.xls.

Cykliczne materiały analityczne NBP. Rynek nieruchomości - Raport roczny, http://www.nbp.pl/ home.aspx?f=/publikacje/rynek_nieruchomosci/index1.html;dok.PDF. 